PAEDAGOGIA ChristianA

I /23(2009) - ISSN 1505-6872

Adam Orczyk*

Radom

\title{
Chrześcijańska pedagogika personalistyczna a współczesne koncepcje wychowania
}

Chrześcijańska pedagogika personalistyczna stanowi przykład refleksji naukowej nad rzeczywistością wychowania (w teorii i praktyce) z uwzględnieniem danych płynących z Objawienia Bożego (biblijnego) i rozwoju wychowawczej myśli Kościoła. Wywodzi swoją specyfikę i odrębność (jako dyscyplina pedagogiczna) z przesłanek światopoglądowych, filozoficznych, teologicznych i religijnych. Jest postrzegana jako dyscyplina pedagogiczna, która znajduje się pod wpływem i w duchowym klimacie religii chrześcijańskiej oraz uznaje Objawienie jako tzw. „kryterium negatywne”, tzn. poddające krytyce ewangelicznej wypracowane przez pedagogikę koncepcje, zwłaszcza w kwestiach stwierdzeń antropologicznych i aksjologicznych ${ }^{1}$.

Istotę personalizmu w wymiarze edukacyjnym F. Adamski streszcza w następujących słowach:

Personalizm akcentuje fakt niepowtarzalności osoby oraz jej prawo do wyboru własnej drogi rozwoju i doskonalenia osobowego - włączając w to wszelkie formy i poziomy kształcenia i wychowania. Godność i wolność osoby przeciwstawia się jakiemukolwiek sterowaniu tym wychowaniem, manipulowaniu treściami kształcenia i wychowania, jego zinstrumentalizowaniu czy zmonopolizowaniu - co nie oznacza, że wychowanie nie powinno być kierowane. Wręcz przeciwnie, powinno być skierowane na wartości i chronione przed treściami i sytuacjami stanowiącymi antywartości. Ażeby mogło być pełne, powinno być dziełem wielu ośrodków oddziaływania: rodziny, instytucji szkoły, Kościoła, związków i stowarzyszeń mło-

* Ks. dr Adam Orczyk, adiunkt w Instytucie Teologicznym w Radomiu na Wydziale Teologicznym Uniwersytetu Kardynała Stefana Wyszyńskiego w Warszawie.

${ }^{1}$ Por. M. Nowak, Podstawy pedagogiki otwartej. Ujęcie dynamiczne w inspiracji chrześcijańskiej, Lublin 1999, s. 82-89. 
dzieżowych, środków masowego przekazu oraz norm społeczno-prawnych leżących u podstaw kultury każdego społeczeństwa. Punktem odniesienia do wszelkich oddziaływań wychowawczych jest odpowiedź na pytanie o człowieka i jego miejsce w porządku bytów stworzonych. Z odpowiedzi bowiem na to pytanie wynika cel, istota i przebieg procesów wychowawczych².

Pedagogika personalistyczna, na bazie której rozwija się pedagogika chrześcijańska, przyjmuje w koncepcji świata i człowieka wzajemną zależność takich elementów, jak względny indeterminizm, wolność i transcendencja; uznaje, że człowiek jest w stanie dociekać prawdy obiektywnej; stoi na stanowisku trwałości i obiektywizmu wartości. Dlatego, wkraczając do dyskusji pedagogicznych, pedagogika personalistyczna nie waha się przyjmować postawy krytycznej, by bronić praw i godności osoby oraz pobudzać do czujności wobec różnych stwierdzeń, jakie pojawiają się w pedagogice, stanowiąc rodzaj „świadomości krytycznej" w odniesieniu do pedagogiki i wychowania ${ }^{3}$.

W przeciwieństwie do każdego innego nurtu pedagogiki personalizmu, w którym eksponuje się przede wszystkim wartość i niepowtarzalność osoby ludzkiej, w pedagogice chrześcijańskiej następuje wyraźne przesunięcie akcentu na Boga, który najpełniej objawił się człowiekowi w Jezusie Chrystusie. Wynika stąd szereg istotnych przesłanek dla teorii i praktyki wychowania, jak chociażby miłość do człowieka, prawda o ojcostwie Boga, braterstwo w stosunkach między ludźmi, perspektywa zmartwychwstania ${ }^{4}$.

\section{Wielość teorii i nurtów pedagogiki (wychowania)}

Na przestrzeni minionego wieku zdołano wypracować szereg teorii i kierunków wychowania, przyjmując jako kryterium różnicujące przede wszystkim założenia filozoficzne, idee światopoglądowe, osiagnięcia nauk o człowieku i przemiany społeczno-kulturowe.

Ludwik Chmaj (1888-1959), wybitny historyk filozofii i pedagog, jest autorem klasycznego opracowania Kierunki i prady pedagogiki współczesnej, wydanego po raz pierwszy w 1938 r., w którym ukazał najważniejsze prądy w pedagogice, klasyfikowane według założeń antropologicznych. Założenia te - według niego - dają możliwość wyróżnienia teorii: biologicznej, personalistycznej, socjologicznej i humanistycznej. Chmaj uważał, że różnorodność kierunków peda-

${ }^{2}$ F. Adamski, Wprowadzenie: personalizm - filozoficzny nurt myślenia o człowieku $i$ wychowaniu, w: tenże (red.), Wychowanie personalistyczne. Wybór tekstów, Kraków 2006, s. 13.

${ }^{3}$ Por. M. Nowak, Wychowanie w personalizmie, „Chrześcijanin w świecie” 4 (1993), s. $66-67$.

${ }^{4}$ Por. tenże, Pedagogika chrześcijańska: jej podstawy, rozwój i aktualny stan, „Rocznik Pedagogiczny" 27 (2004), s. 46. 
gogicznych wypływała ze związków z innymi dyscyplinami, dającymi podstawy teoriom wychowawczym 5 .

Stefan Kunowski (1909-1977), profesor Katolickiego Uniwersytetu Lubelskiego i wieloletni kierownik Zakładu Pedagogiki tej uczelni, wymienia trzy główne systemy wychowawcze, które ostatecznie ukształtowały się w XX wieku: system wychowania chrześcijańskiego, system wychowania liberalnego i system socjalistyczny wychowania ${ }^{6}$.

Współczesny amerykański filozof edukacji G. L. Gutek, autor opracowania Filozoficzne i ideologiczne podstawy edukacji, analizując najważniejsze systemy filozoficzne i ideologiczne, które ukształtowały współczesną myśl i praktykę edukacyjna, identyfikuje ich filozoficzny rodowód. Wśród filozofii edukacyjnych wymienia on: idealizm, realizm, realizm teistyczny (tomizm), naturalizm, pragmatyzm, egzystencjalizm i filozofię analityczną. Teorie edukacyjne biorą swój początek także z ideologii. Do szczególnie znaczących ideologii zalicza on: nacjonalizm, etnonacjonalizm, liberalizm, konserwatyzm, utopizm, marksizm i totalitaryzm. Przeprowadzona analiza pozwoliła na ustalenie trzech zasadniczych - zdaniem autora - typów teorii edukacyjnych: 1) teorie wyprowadzone lub wywiedzione z różnych systemów poznawczych lub myślowych, takich jak filozofie czy ideologie: esencjalizm, perenializm (w tym perenializm religijny); 2) teorie, które powstały jako reakcja na systemy filozoficzno-ideologiczne: progresywizm, rekonstrukcjonizm społeczny; 3) teorie, które wywodzą się z praktyki: „ruch na rzecz skutecznej szkoły”. Zastosowanie powyższych teorii uwidacznia się w poszczególnych kierunkach wychowania ${ }^{7}$.

Bogusław Śliwerski w swoim kluczowym opracowaniu Wspótczesne teorie i nurty wychowania odwołuje się do badań porównawczych L. Kohlberga i R. Mayera, którzy wskazali w swej pracy Development as the Aim of Education (Rozwój jako cel wychowania) na aktualność trzech prądów zachodnich ideologii wychowania: romantyzmu (J. J. Rousseau, M. Montessori, A. S. Neill), transmisji kulturowej (J. F. Herbart) i progresywizmu (J. Dewey, J. Piaget). Według ideologii romantycznej - to, co pochodzi od dziecka, jest najważniejszym aspektem jego rozwoju. Według ideologii transmisji kulturowej - wychowanie jest przekazem zdobyczy kulturowych społeczeństwa. Według ideologii progresywnej - wychowanie powinno podtrzymywać naturalne interakcje dziecka z rozwijającym się społeczeństwem lub środowiskiem ${ }^{8}$.

W odwołaniu do wspomnianych powyżej teorii (systemów, idei) wychowania powstało wiele ujęć i opracowań współczesnych prądów i kierunków pedagogicznych.

${ }^{5}$ Por. W. Szulakiewicz, Historia oświaty $i$ wychowania w Polsce 1918-1939. Studium historiograficzne, Toruń 2000, s. 127-130.

${ }^{6}$ Por. S. Kunowski, Podstawy wspótczesnej pedagogiki, Warszawa 1993, s. 88-93.

${ }^{7}$ Por. G. L. Gutek, Filozoficzne i ideologiczne podstawy edukacji, thum. A. Kacmajor, A. Sulak, Gdańsk 2003.

${ }^{8}$ Por. B. Śliwerski, Współczesne teorie i nurty wychowania, Kraków 2005, s. 31-33. 
Stefan Wołoszyn w monografii Nauki o wychowaniu w Polsce $w$ XX wieku wyodrębnił trzy wielkie nurty teoretyczne (prądy, kierunki): pedagogikę psychologiczna, pedagogikę socjologiczną i pedagogikę kultury, nazywaną przez niektórych również pedagogiką humanistyczną albo pedagogiką personalistyczną9.

Włoski filozof wychowania C. Nanni wśród kierunków teoretycznych (teorii lub tzw. „filozofii wychowania”), obecnych w świecie wychowania i pedagogice, wylicza: kierunek marksistowski, kierunek personalizmu, kierunek laicki lub neo-oświeceniowy, kierunek emancypacyjny i neoradykalny, kierunek technologiczno-funkcjonalny ${ }^{10}$.

W opracowaniu Pedagogika. Podręcznik akademicki zamieszczono 19 najbardziej charakterystycznych dla współczesności kierunków i prądów pedagogicznych. Należą do nich: 1) pedagogika pozytywistyczna, 2) pedagogika kultury, 3) pedagogika personalistyczna, 4) pedagogika egzystencjalna, 5) pedagogika religii, 6) pedagogika Nowego Wychowania, 7) pedagogika waldorfska, 8) pedagogika pragmatyzmu, 9) pedagogika Marii Montessori, 10) pedagogika Janusza Korczaka, 11) pedagogika Petera Petersena, 12) pedagogika Celestyna Freineta, 13) pedagogika krytyczna, 14) pedagogika antyautorytarna, 15) pedagogika emancypacyjna, 16) pedagogika międzykulturowa, 17) pedagogika ekologiczna, 18) pedagogika negatywna, 18) pedagogika postmodernizmu ${ }^{11}$.

Bogusław Śliwerski we wspomnianej już monografii Wspótczesne teorie i nurty wychowania prezentuje 18 następujących koncepcji: 1) pedagogika filozoficzno-normatywna, 2) chrześcijańska pedagogika personalno-egzystencjalna, 3) pedagogika społeczno-personalistyczna, 4) pedagogika serca, 5) duchowa pedagogia miłości, 6) pedagogia niedyrektywna, 7) pedagogia nieautorytarna, 8) pedagogika Gestalt, 9) pedagogika wychowania integralnego, 10) pedagogika antyautorytarna, 11) pedagogika radykalnego humanizmu, 12) krytyczna nauka o wychowaniu, 13) pedagogika emancypacyjna, 14) pedagogika międzykulturowa, 15) dekonstrukcja a pedagogika przezwyciężania obcości, 16) pedagogika analityczno-krytyczna, 17) antypedagogika - postpedagogika, 18) pedagogika [w] ponowoczesności.

Z kolei T. Kukołowicz do współczesnych koncepcji wychowania zalicza: nurt neoillumenistyczny (laicki), nurt radykalno-emancypacyjny, nurt technologiczno-funkcjonalny, antypedagogikę, nurt marksistowski, nurt personalistyczny ${ }^{12}$.

${ }^{9}$ Por. S. Wołoszyn, Nauki o wychowaniu w Polsce w XX wieku. Próba syntetycznego zarysu na tle powszechnym, Kielce 1998.

${ }^{10}$ Por. C. Nanni, Educazione e scienze dell'educazione, Roma 1986, s. 115-126.

${ }^{11}$ Por. Z. Kwieciński, B. Śliwerski (red.), Pedagogika. Podręcznik akademicki, t. 1, Warszawa 2004, s. 184-464.

${ }^{12}$ Por. T. Kukołowicz, Nowe koncepcje wychowania, „Chrześcijanin w świecie” 4 (1993), s. 53. 


\section{Próba oceny dominujących teorii i nurtów wychowawczych}

„Jeszcze do niedawna - zdaniem B. Śliwerskiego - było tak, że uprawiający pedagogikę mieli skłonność do szukania w poglądach innych przede wszystkim błędów i wobec tych błędów musieli zająć stanowisko. Tymczasem współczesnej pedagogice powinno zależeć na tym, żeby szukać tego, co ich łączy, co jest wspólne, co prowadzi do bliższego poznania prawdy o kształceniu i wychowaniu drugiego człowieka" 13 .

Trudno kwestionować słuszność tego poglądu. W praktyce jednak realizacja powyższego postulatu może nastręczać pewne trudności. Wynikają one m.in. stąd, że tak dalece posunięte zróżnicowanie współczesnych koncepcji wychowania dokonało się na drodze opozycji jednych stanowisk względem drugich. Była to bardzo często opozycja o charakterze ideologicznym, którą po dziś dzień trudno przełamać.

Nie ulega wątpliwości, że pełna i wszechstronna ocena wyliczonych powyżej kierunków i prądów pedagogicznych daleko wykracza poza ramy niniejszego artykułu i intencje autora, nawet przy założeniu, że przyjmie się w miarę precyzyjne i jednoznaczne kryteria oceny. Nie przestaje również istnieć ryzyko błędnej interpretacji założeń poszczególnych kierunków oraz subiektywizmu w ich odczytaniu. Pewną pomocą w tym zadaniu może okazać się cytowany już artykuł T. Kukołowicz Nowe koncepcje wychowania, gdzie autorka zasygnalizowała pewne zagrożenia wychowawcze, jakie niesie ze sobą określona teoria pedagogiczna. W końcowej ocenie analizowanych przez siebie koncepcji autorka stwierdza:

Przedstawione powyżej nurty, obecne w polskiej pedagogice, przynoszą i podkreślają niektóre ważne $\mathrm{w}$ wychowaniu elementy. Wspólnym, cennym ich znamieniem jest koncentracja na osobie wychowanka i rozpatrywanie wychowania w odniesieniu do niego. Tylko niektóre z tych nurtów odchodzą od tej tendencji, np. nurt technologiczno-funkcjonalny. Jednak warto podkreślić tę koncepcję z uwagi na to, że do niedawna wychowanie i kształcenie ujmowane było jako działalność służąca przede wszystkim celom społecznym, a nie wychowankowi. Jakie zatem zadania stawia się wychowaniu? Zarówno pedagogika neo-illumenizmu, jak i radykalnoemancypacyjna, a także antypedagogika podkreślają jako istotne zadanie wyzwolenie wychowanka. Rozumiane jest ono różnie - jako wyzwolenie od wychowania, bo traktuje się je jako przymus i przemoc wobec dziecka, a także jako wyzwolenie od wszystkiego: absolutów, wszelkich prawd zastanych, ostatecznie i jedynie shusznych. Chodzi również o uwolnienie się od skutków postępu technologicznego. Tak rozumiana wolność prowokuje do postawienia pytania: czy można człowieka w ogóle nie wychowywać, nie nadawać mu kierunku? Czy w rzeczywistości może zaistnieć taka sytuacja?

${ }^{13}$ B. Śliwerski, Wstęp, w: Z. Kwieciński, B. Śliwerski (red.), dz. cyt., s. 194. 
Są i inne zadania skierowane do wolności człowieka. Pedagogika personalistyczna stwierdza, że człowiek jest wolny, ale jego wolność może być zagrożona przez niewłaściwe wybory, przez niezgodną z prawdą kwalifikację dobra. Wobec różnych diagnoz stanu wolności człowieka powstaje pytanie, czy zniewolenie wywołane jest przez czynniki zewnętrzne, jak twierdzi antypedagogika, czy też tkwią one w człowieku? Odpowiedź na powyższe pytania pozwoli na właściwe wychowanie do wolności.

W ujęciu neo-illumenizmu szczególne znaczenie ma położenie nacisku na formację intelektualną, na postawę krytyczności. Pedagogika radykalno-emancypacyjna doda do tego postawy ciaglego zwatpienia, sceptycyzmu, odmowy samozadowolenia i pewności, przeciwstawianie się religijnej indoktrynacji i politycznej manipulacji, a także kształtowanie tolerancji, gotowość dialogu oraz otwieranie się na nowe, wypowiadane we własnym imieniu wartości, na nowe znaczenie i nowy sposób doświadczania świata. Pedagogika dialogu dopełni to zadanie tym, że relacja wychowawca-wychowanek to stałe zapytywanie, będące sposobem bycia, a w ten sposób uczenie się siebie i świata. Kształtowanie zaproponowanych postaw prowadzi w konsekwencji do uznania nieistnienia prawdy obiektywnej, odrzucenia zasad, praw, a w końcu do subiektywnej rzeczywistości ${ }^{14}$.

Tymczasem prawidłowe wychowanie nie może podawać w wątpliwość wszelkich praw, zasad i wartości. Subiektywizacja i relatywizacja prawd i wartości, całkowite przekreślanie elementu dyrektywności (wychowania intencjonalnego) w stosunku do wychowanka, jak również inne kontrowersyjne rozwiązania prowadziłyby bowiem do sytuacji, w której uzyskanie odpowiedzi na wewnętrzne potrzeby wychowawcze człowieka stawałoby się niemożliwe ${ }^{15}$.

Na kanwie tych cennych spostrzeżeń i przy bliższym zapoznaniu się z dominującymi nurtami w wychowaniu można wskazać szereg istniejących różnic między nimi a chrześcijańską pedagogiką personalistyczną. Dotyczą one m.in. przyjętych przesłanek natury antropologiczno-aksjologicznej, a także szeregu innych kwestii, jak np.: pojmowanie natury i celowości wychowania i, co się z tym wiąże, stosunek do pedagogiki jako nauki; stosunek do możliwości poznawczych i wartości etyczno-moralnych; pojmowanie wolności i korzystanie z niej; redefiniowanie ról i funkcji osób i instytucji wychowawczych.

\subsection{Rozbieżności w sferze podstaw antropologicznych i aksjologicznych wychowania}

Konkretne systemy wychowawcze w teorii i praktyce bazują zawsze na określonej filozofii człowieka. Jest rzeczą oczywistą, że filozofia nie tworzy pro-

${ }^{14}$ T. Kukołowicz, dz. cyt., s. 56-57.

${ }^{15}$ Por. tamże, s. 57-58. 
gramów wychowania, ale pyta, czego warto nauczać i dlaczego warto nauczać i wychowywać. Wszelkie systemy oświatowe, jak i wszelkie typy instytucji edukacyjnych wspierają dobór treści edukacyjnych określonymi rozstrzygnięciami filozoficznymi. Dla filozofii wychowania podstawowe pytanie brzmi: Kim jest człowiek? Jakie są antropologiczne podstawy wychowania? Pedagogika i antropologia wyrastają z tego samego źródła i dążą do tego samego celu. Koncepcja człowieka stanowi klucz do każdego modelu wychowania i rzutuje na jego cele ${ }^{16}$.

Zdaniem wielu autorów, we współczesnej pedagogice polskiej brakuje wyczerpującej i usystematyzowanej refleksji na temat antropologicznych podstaw i teleologii wychowania. Z niewłaściwych koncepcji człowieka (empiryczno-scjentystycznej, materialistycznej, naturalistycznej, duchowej, socjologicznej, psychoanalitycznej, egzystencjalistycznej) wynika jednostronność przyjmowanych celów. Tymczasem człowiek jest bytem wielowymiarowym. W każdym z tych wymiarów kryje się cząstka prawdy ${ }^{17}$. Dlatego, by przełamać jednostronne ograniczenia, trzeba - zdaniem M. Nowaka - odrzucić antropologiczny redukcjonizm, który źle odpowiada szerokim możliwościom aktualnej sytuacji życia człowieka, i przyjąć rozwiązania wypracowane w ramach bliskiej chrześcijaństwu koncepcji (pedagogice) integralnej ${ }^{18}$.

Pełne spojrzenie na człowieka powinno uwzględniać wszystkie płaszczyzny jego rozwoju, które mieszczą się w obszarze antropologii biologicznej, społecznej, kulturowej, filozoficznej i teologicznej. Antropologia pedagogiczna, zbierając niejako osiagnięcia poprzednich, pozwala bardziej precyzyjnie określić cel i ideał wychowania.

Tak jak informują nas poszczególne dyscypliny antropologii, wszystkie zgadzają się co do tego, że człowiek jest wychowalny i że człowieka trzeba wychowywać, aby mógł funkcjonować w tych wszystkich zakresach, które podejmują poszczególne działy antropologii. Coraz bardziej też dojrzewa przekonanie, że w tym względzie jest potrzebne działanie interdyscyplinarne, które łączyłoby różne dziedziny, dyscypliny antropologiczne, według ich własnej charakterystyki i postępowania. W ten też sposób rodzi się zapotrzebowanie na dzieło interdyscyplinarne w zakresie antropologii, zdolne wydobyć złożoność i bogactwo istoty ludzkiej, człowieka ${ }^{19}$.

Obok troski o określenie podstaw antropologicznych wychowania, drugą istotną kwestią jest wybór właściwej podstawy aksjologicznej wychowania

\footnotetext{
${ }^{16}$ Por. S. Chrost, Koncepcja człowieka a teleologia wychowania, Sandomierz 2008, s. 9.

${ }^{17}$ Por. tamże, s. 13.

${ }^{18}$ Por. M. Nowak, Filozofia czlowieka podstawa filozofii wychowania, w: F. Adamski, dz. cyt.,

${ }^{19}$ Tamże, s. 145.
} s. 149-153. 
i związana z tym problematyka wartości ${ }^{20}$. Nawet jeżeli przyjmie się, że kategoria „powinności” należy do kardynalnych pojęć aksjologicznych pedagogiki, to faktor „powinien”, „powinno się” nie jest jednoznacznie pojmowany ${ }^{21}$. Wiele współczesnych koncepcji wychowania świadomie odrzuca wartość sądów normatywnych w wychowaniu. Brak też aksjologicznych stałych „punktów odniesienia" jako fundamentów teorii i praktyki pedagogicznej, a nawet następuje odwrócenie od problematyki celów i wartości ${ }^{22}$.

W przypadku pedagogiki postmodernistycznej w ciagłych próbach znalezienia odpowiedzi na dramatyczne pytanie o źródło wartości i ideałów nie sięga się już do natury, tradycji, historii, religii; co prowadzi do tzw. „pedagogiki milczenia” lub ,pedagogiki nihilistycznej”. Postmodernizm utrudnia również człowiekowi zajęcie miejsca w perspektywie transcendencji, odrywając go od Boga i postulując całkowite wyzwolenie się od wszelkiej religii. Znosi tym samym obiektywne i uniwersalne dobro moralne, odrywa byt ludzki od sacrum. Nawet jeżeli mówi się o „uszanowaniu wielkich opowieści religijnych”, to traktuje się je w sposób mityczny ${ }^{23}$.

Dla Z. Kwiecińskiego współczesność, jako okres „kryzysu formacji kulturowej” i „czas przesilenia”, naznaczona jest pluralizmem kulturowym i indywidualizmem, co niewątpliwie przekłada się także na płaszczyznę edukacyjną ${ }^{24}$.

Wskazując na konsekwencje wychowawcze pluralizmu aksjologicznego, F. Adamski stwierdza m.in.:

Rozbicie jednolitego systemu wartości i norm jednostkowych i społecznych oznacza, że społeczeństwo przestaje być 'całością moralną' rządzącą się wspólnie obowiązującymi normami. Dzieje się tak dlatego, że pluralizm strukturalno-aksjologiczny występujący w mikroskali (indywidualne wybory) łatwo przesuwa się na płaszczyznę makrospołeczna. $Z$ bogatego 'rynku wartości' coraz szersze rzesze coraz chętniej biorą to, co łatwe, atrakcyjne, a zwłaszcza niewymagające wyrzeczeń. W dalszej kolejności i konsekwencji w oczywisty sposób prowadzi to do wytworzenia się próżni aksjologicznej, której cechą znamienną jest to, że dla poszczególnego, konkretnego człowieka nic nie jest oczywiste: nie ma bowiem jednolitego punktu

${ }^{20}$ Por. R. Schulz, O statusie i zadaniach aksjologii pedagogicznej, w: T. Kukołowicz, M. Nowak (red.), Pedagogika ogólna. Problemy aksjologiczne, Lublin 1997, s. 23-31; zob. K. Olbrycht, Wychowanie a wartości, w: T. Kukołowicz, M. Nowak (red.), dz. cyt., s. 45-51; K. Denek, Aksjologiczne aspekty edukacji szkolnej, Toruń 1999; Z. Frączek, Edukacja aksjologiczna wobec potrzeb wspótczesności, Rzeszów 2002.

${ }^{21}$ Por. S. Wołoszyn, Kategoria powinności jako podstawowa aksjologiczna kategoria pedagogiki-jak jq rozumieć?, w: T. Kukołowicz, M. Nowak (red.), dz. cyt., s. 11-12.

${ }_{22}$ Por. M. Nowak, Od kontestacji do powrotu problematyki aksjologicznej i teleologicznej w pedagogice ogólnej, w: T. Kukołowicz, M. Nowak (red.), dz. cyt., s. 33-35.

${ }^{23}$ Por. B. Śliwerski, Wspótczesne teorie, s. 384-385.

${ }^{24}$ Por. Z. Kwieciński, Pluralizm - pedagogicznq szansq czy brzemieniem?, w: T. Kukołowicz, M. Nowak (red.), dz. cyt., s. 15-16. 
odniesienia. Każda sytuacja - i to zarówno w swym wymiarze indywidualnym, jak i społecznym - może być oceniana, wartościowana z różnej perspektywy. A stąd - jak wiadomo - prowadzi droga do nieuniknionego relatywizmu moralnego: dla koherencyjnego systemu wartości i norm, który by scalał społeczeństwo i wyznaczał sposoby działania, nie ma tu już miejsca ${ }^{25}$.

\subsection{Rozbieżności w sferze postrzegania procesu wychowawczego i natury wychowania}

W tradycyjnym znaczeniu wychowanie to oddziaływanie ludzi dorosłych (wychowawców) na dzieci i młodzież (wychowanków) w celu kształtowania w nich postaw, wartości, dążeń, uczuć. Jest to proces, który dokonuje się w kontekście społecznym oraz opiera się na działalności społecznie zorganizowanej. Wychowanie w sensie ścisłym jest działaniem celowym i zamierzonym. To wychowawca podejmuje świadome działania, mające na celu przyjęcie przez wychowanka nowych norm zachowań i ich umocnienie. Jednocześnie między wychowawcą a wychowankiem zachodzi wzajemne oddziaływanie - relacja dwustronna, tzn. wychowawca oddziałuje na wychowanka, ale także wychowanek oddziałuje na wychowawcę. Ponadto ich kontakt opiera się na wymianie informacji w klimacie dialogu edukacyjnego ${ }^{26}$.

$\mathrm{Z}$ tak rozumianym wychowaniem nie godzą się twórcy antypedagogiki. Nurt ten wyrósł z zawiedzionych nadziei na moc wychowania, zwłaszcza zinstytucjonalizowanego, jakie objawił wiek XX. Kierunek ten odrzuca wychowanie rozumiane jako świadomy proces formacyjny, podporządkowujący dziecko autorytetowi osoby dorosłej, wychodząc z założenia, że należy odrzucić wszelkie poglądy, które dotychczas uzasadniają oraz utrzymują władzę oraz przywileje osób dorosłych w stosunku do dzieci. Podstawową tezą tego kierunku staje się twierdzenie, że każde intencjonalne działanie wobec wychowanka jest jego okaleczeniem. Przedstawiciele antypedagogiki określają dotychczasowy dorobek myśli i praktyki pedagogicznej mianem „czarnej pedagogiki” skierowanej przeciwko dziecku (K. Rutschky). Domagają się odrzucenia wszelkich roszczeń wychowawczych ze strony tradycyjnych instytucji wychowawczych (rodzina, szkoła, Kościół, państwo) w imię „uwolnienia dziecka od wychowania"27.

W antypedagogice powraca znany pogląd, że człowiek jest od urodzenia w pełni wartościowy, autonomiczny, potrafi decydować o sobie i swoim wychowaniu. Istotne jest stworzenie mu warunków do spontanicznego, niczym nieogra-

${ }^{25}$ F. Adamski, Pluralizm wartości i wychowanie, w: tenże (red.), dz. cyt., s. 274-275.

${ }^{26}$ A. Solak, Człowiek i jego wychowanie. Zagadnienia wybrane, Tarnów 2001, s. 14.

${ }^{27}$ Por. O. Speck, Być nauczycielem. Trudności wychowawcze w czasie zmian społeczno-kulturowych, Gdańsk 2005, s. 141-147. 
niczonego rozwoju. Akcentuje się godność dziecka oraz jego prawo do samostanowienia we wszystkich obszarach życia, a relacje dorosłych z wychowankami opiera na dialogu partnerskim. Do antypedagogiki odwołują się niektórzy przedstawiciele ruchu szkół alternatywnych, którzy nie godzą się z omnipotencją tradycyjnego systemu oświaty ${ }^{28}$.

Stefan Wołoszyn uważa, że nurt ten

radykalnie przeciwstawia się wszelkiej pedagogice wychowania autorytarnego, represyjnego, opartego na przedmiotowym i manipulacyjnym traktowaniu wychowanka. Wychowanie takie nie jest uprawnione, narzuca bowiem dziecku gotowy, „cudzy” system wartości. Formułą ogólną antypedagogiki jest wspierać, nie wychowywać, co pozwala budować autentyczne, oparte na wzajemnej przyjaźni stosunki między dorosłymi a dorastającymi ${ }^{29}$.

Doświadczenie pokazuje jednak, że „wspieranie” bez „wychowania” zawodzi, podobnie jak pogląd, „by uczyć, a nie wychowywać”. W środowisku niemieckim podkreśla się skrajność tego nurtu, który de facto został zbudowany na błędnie zinterpretowanych przesłankach i „ma niewiele do zaproponowania komuś, kto w warunkach współczesnych zajmuje się dziećmi”"30.

Krytycy antypedagogiki podają $\mathrm{w}$ wątpliwość jej podstawowe założenie (sformułowane przez H. von Schoenebecka), że dziecko jest ,istotą autonomiczną i samostanowiącą", tzn. jest zdolne do podejmowania odpowiedzialności za własną drogę życiową oraz dokonywanie istotnych wyborów, do czego przecież konieczne jest doświadczenie oraz elementarna wiedza o możliwych konsekwencjach podejmowanych decyzji oraz czynów ${ }^{31}$. Ponadto zwraca się uwagę na następujące fakty:

1. Obciążanie pedagogiki jedynie negatywnymi aspektami wpływów wychowawczych przy całkowitym milczeniu na temat pozytywnych stron oddziaływania pedagogicznego prowadzi do uproszczonej wizji czarno-białego świata. Nie można generalizować działań pseudowychowawczych jako jedynych i powszechnych. Współcześnie mówi się o wychowaniu jako o dialogu, wyzwalaniu, wspieraniu wychowanka, a nie tyle o jego urabianiu przez dorosłych.

2. Antypedagogika nie powinna odżegnywać się od dziedzictwa myśli i praktyki pedagogicznej, skoro sama na tej bazie buduje swoje przesłanki.

3. Problem wychowania nie zniknie z obszaru społecznych czy indywidualnych doświadczeń lub teorii, kiedy zażąda się jego systematycznej eliminacji,

${ }^{28}$ T. Kukołowicz, dz. cyt., s. 55.

${ }^{29}$ S. Wołoszyn, Nauki o wychowaniu w Polsce w XX wieku. Próba zarysu encyklopedycznego, Warszawa 1992, s. 69, cyt. za: W. Kamiński, Teoria wychowania (swoistość, zadania, perspektywy rozwoju), w: L. Turos (red.), Pedagogika ogólna i subdyscypliny, Warszawa 1999, s. 147.

${ }^{30}$ O. Speck, dz. cyt., s. 145-146.

${ }^{31}$ Por. B. Milerski, B. Śliwerski, Pedagogika. Leksykon PWN, Warszawa 2000, s. 17. 
postulując odstapienie od wychowania na rzecz wspierania czy towarzyszenia dziecku w rozwoju.

4. Wyobrażenie o wyzwoleniu dzieci od wychowania jest idealistyczną i metafizyczną iluzją, gdyż nie bierze pod uwagę dialektycznej jedności swobody i przymusu, praw i obowiązków, jednostki i społeczeństwa. Jeśli się nie wychowuje dziecka, to wszystko wymyka się spod kontroli i może dojść do wielu wypaczeń. Demokracja nie musi być najwyższą wartością w wychowaniu.

5. Trudno zgodzić się z ukazywaną przez antypedagogikę kwestią różnic między dziećmi a dorosłymi. Różnice niewątpliwie istnieją, ale to nie dzieci mają problem z dorosłymi, tylko dorośli ze swoimi dziećmi. Dostrzega się w antypedagogice wręcz nienawistną wizję dorosłości, która jest elementem pewnej wizji świata. Antypedagogika popełnia błąd, przenosząc ideał człowieka dorosłego (wolnego, w pełni rozwiniętego, autonomicznego) na dziecko, twierdząc, że typowe dziecko jest właśnie takie. Błędne jest zatem odwrócenie piramidy rozwojowej i zakwestionowanie sekwencji rozwojowych przez przypisywanie dziecku szczytu rozwojowego (szczytu dorosłości).

6. Antypedagogika wychodzi z założenia, że rozwój dziecka dokonuje się w sposób naturalny, że dziecko będzie umiało dokonywać wyboru zgodnie z zasadą: „Ja wiem lepiej, niż ty, co jest dla mnie dobre”. Tymczasem psychologia rozwojowa stwierdza, iż ów rozwój dziecka wymaga stworzenia mu pewnych warunków pokonywania trudności (pewnego oporu). Muszą zachodzić określone momenty napięcia i jego likwidacji, pewne momenty kryzysu czy niepowodzeń, które z kolei wymagają określonej stymulacji z zewnątrz, czyjejś ingerencji. Są przecież takie sytuacje czy zdarzenia, w których odwoływanie się do natury i samowiedzy dziecka jest bezskuteczne, a wówczas to dorosły „lepiej wie, niż dziecko, co jest dla niego dobre" 32 .

Wszelkie tendencje obiektywistyczne, fundamentalne, systemowe i całościowe w naukach o wychowaniu krytykowane są natomiast ze strony pedagogiki postmodernistycznej. Kierunek ten odwołuje się do „,nowej świadomości” współczesnego człowieka, który żyje w świecie zindywidualizowanym, skomercjalizowanym i zmerkantylizowanym, naznaczonym przypadkowością i ryzykiem. W świecie tym dominuje poczucie nietrwałości. Posługując się metodą dekonstrukcji, twórcy i propagatorzy tego kierunku (H. Arendt, J. Derrida, N. Postman, R. Rorty) starają się ukazać fragmentaryczny, relatywny i regionalny charakter teorii pedagogicznych. Celem tych działań jest przede wszystkim uświadomienie dotychczasowych uwarunkowań procesów edukacyjnych, a także pedagogicznych przesądów i przekłamań, które - ich zdaniem - odzwierciedlają naiwny realizm terminologiczny (np. gdy mówi się o prawach rodziców, dobru dziecka, dobru społeczeństwa itp. $)^{33}$.

\footnotetext{
${ }^{32}$ B. Śliwerski, Współczesne teorie, s. 343-344.

${ }^{33}$ Por. B. Milerski, B. Śliwerski, dz. cyt., s. 155.
} 
W świetle pedagogiki postmodernizmu każdy powinien mieć możliwość pełnej samorealizacji. Wartości przestają być dla postmodernistów „obiektywną miarą", ustanowioną przez autorytet lub przez tradycję. Są one szeroko rozumianymi „ramami orientacyjnymi”, stwarzanymi i zmienianymi przez procesy polityczne, rozwój społeczny i techniczny oraz przez modę ${ }^{34}$. Moralność jest zastępowana przez estetykę, stąd np. powołując się na „wolność sztuki”, lekceważy się przekonania religijne i moralne innych.

W postmodernizmie nie chodzi o poszukiwanie optymalnego wychowania, a sami pedagodzy świadomie zrzekają się odpowiedzialności wychowawczej. Nie obowiązują również takie kategorie wychowawcze, jak: autorytet, posłuszeństwo, przestrzeganie norm, postępowanie według wzorów, dotrzymywanie umów. Dominującą kategorią w społeczeństwie postmodernistycznym staje się dobrowolnośćs ${ }^{35}$. W imię pedagogicznej emancypacji należy „przezwyciężać potęgę tradycji” i „rozbijać zasklepienia konwenansów”, uwalniać się od „autorytaryzmu filozofii", co ma przynieść ludziom ulgę, pozbawi ich poczucia winy i zdejmie z nich ciężar przesadnych i niepotrzebnych obowiązków ${ }^{36}$.

Pewną zaletą pedagogiki postmodernistycznej jest swoiście pojmowane dążenie do „odkłamania” rzeczywistości społeczno-wychowawczej i związanych z tym zagrożeń. Krytycy tego kierunku wskazują jednak na wiele ,ironicznych paradoksów świadomości postmodernistycznej" o charakterze filozoficzno-epistemologicznym ${ }^{37}$.

\subsection{Rozbieżności w sferze ksztaltowania postaw poznawczych i moralnych}

Głównym celem wychowania według nurtu krytycznego jest ukształtowanie postawy racjonalistycznej. Człowiek ma być gotowy do kwestionowania wszelkich absolutów, prawd, powszechnie akceptowanych rozwiązań. Nie ma stałej prawdy, ale jest ona ciagle odkrywana na nowo, świat stale się zmienia, wobec tego nie ma niezmiennych absolutnych zasad. Natura człowieka to efekt wpływu kultury. Człowiek powinien odznaczać się także sceptycyzmem wobec przekazywanych treści i prawd religijnych, jak również wobec programów politycznych. Jednocześnie powinien być tolerancyjny, gotowy do podjęcia dialogu z każdą ideą i wizją świata ${ }^{38}$.

Propagatorzy nurtu radykalno-emancypacyjnego utrzymuja, że człowiek żyje w kręgu tzw. „,wiedzy milczącej”, którą można określić jako ukryty program

\footnotetext{
${ }^{34}$ B. Śliwerski, Wspótczesne teorie, s. 364.

${ }^{35}$ Tamże, s. 362.

${ }^{36}$ Tamże, s. 382.

${ }^{37}$ Por. A. Folkierska, Kilka uwag o tzw. postmodernizmie, „Kwartalnik Pedagogiczny” 1-2

${ }^{38}$ Por. T. Kukołowicz, dz. cyt., s. 53-54.
} (1998), s. 3-10. 
sterujący zachowaniami ludzkimi. Program ten ogranicza rozwój człowieka i dlatego trzeba się z niego wyzwolić. Nie ma rzeczywistości obiektywnej (świat pojęć i wartości), lecz człowiek ją stwarza. Akcentuje się możliwość formułowania własnych celów i norm, możliwość wysuwania własnych roszczeń, możliwość domagania się uzasadnień dla tego, co ma mieć charakter obowiązujący dla jednostki i społeczeństwa.

W nawiązaniu do tego nurtu proponuje się tzw. ,pedagogikę dialogu”, której podstawowym założeniem jest negacja rzeczywistości obiektywnej w ogóle. Dla człowieka istnieje tylko to, co jest potwierdzone przez podmiot poznający. Dialog jako narzędzie poznania i relacji dokonuje się za pomocą języka, który nie jest systemem raz na zawsze ustalonych znaczeń, lecz dopiero się je określa ${ }^{39}$.

Zagrożenia dla wolności człowieka dostrzega się przede wszystkim na zewnątrz człowieka, nie zaś w jego sposobie myślenia, poznawania świata, traktowania innych ludzi i przeżywania życia. Zapomina się, że bardzo często prawdziwe przyczyny zniewolenia tkwią przede wszystkim we wnętrzu człowieka, w jego mentalności, w jego postawach, a nawet w jego charakterze ${ }^{40}$.

W odniesieniu do nurtu krytycznego i radykalno-emancypacyjnego należy zauważyć,

że operują one niezwykle chwytliwymi współcześnie hasłami. Są nimi: racjonalność, krytycyzm, wolność, tolerancja, dialog i jego znaczenie w wychowaniu dla pokoju. Natomiast definiowanie wymienionych pojęć budzi wątpliwości. Zostaje zakwestionowana prawda obiektywna, jej miejsce zajęła subiektywność, zakwestionowano istnienie stałych pojęć, zasad. I chociaż zwrócono uwagę na istnienie tak zwanej wiedzy milczącej, zniewalającej człowieka, to wymienione kierunki wpadają w jej sidła. Obok aktualnych i pożądanych haseł, ukrywa się za nimi subiektywizm, relatywizm, pseudo-wolnośćc ${ }^{41}$.

Z kolei teoretycy postmodernizmu odrzucają koncepcje rzeczywistości typowe dla przeszłości, zastępując je postrzeganiem (tłumaczeniem) rzeczywistości jako „lingwistycznej konwencji” lub przyjmując kontekstualną teorię rzeczywistości, według której wszystkie twierdzenia dotyczące wiedzy i prawdy są zrozumiałe jedynie wewnątrz ich kontekstu społecznego. Postmoderniści odrzucają modernistyczną epistemologię i metodę naukową, które opierały się na przekonaniu, że obiektywna prawda istnieje niezależnie od jakichkolwiek symboli, które mogłyby ją wyrażać. Tym samym odrzucają dotychczasową koncepcję nauki. W skrajnych ujęciach prawda (także naukowa) to „lingwistyczna konstrukcja”, podobnie podmiot (dziecko, osoba) to ,lingwistyczna konwencja"42.

${ }^{39}$ Tamże, s. 54.

${ }^{40}$ Por. tamże, s. 56.

${ }^{41}$ Tamże, s. 54.

${ }^{42}$ Por. Z. Melosik, Pedagogika postmodernizmu, w: Z. Kwieciński, B. Śliwerski (red.), dz. cyt., s. $452-456$. 
Postmodernizm prowadzi do relatywizacji prawdy. W poszukiwaniu prawdy człowiek skazany jest na samego siebie, na samotne poszukiwanie hierarchii wartości oraz znaczenia symboli komunikacyjnych, przez co traci on egzystencjalne „punkty odniesienia” i staje w obliczu beznadziejności. Dyskursywny charakter całej rzeczywistości społecznej powoduje, że człowiek nie ma podstaw, jakiegoś punktu wyjścia czy oparcia (jednej prawdy, jednego systemu wartości), które pozwalałyby mu na dokonywanie zmian i rozwój. Jeśli bowiem pomija się pytanie o prawdę i nie uznaje, że każdy człowiek ma konkretną możliwość dojścia do niej, życie zostaje zredukowane do zbioru hipotez, pozbawionych pewnych odniesieńt ${ }^{43}$.

W Polsce mentalność scjentystyczna nauczycieli i wychowawców wykształconych przez pedagogikę realnego socjalizmu może stanowić poważną przeszkodę w rzetelnym podejściu do wiedzy nie tylko religijnej. W przypadku nauczania i wychowania religijnego występuje wciąż tzw. stereotyp scjentystyczny, według którego żadne poznanie, poza przyrodniczym, nie istnieje. Jak się zauważa,

skutki tego nastawienia scjentystycznego szkoły są wielorakie. Dotyczą one zarówno niepotrzebnej ideologizacji przedmiotów przyrodniczych, spychania na margines życia szkolnego humanistyki, niezrozumienie celu nauczania religii w szkole, przeładowania programów informacjami, często zupełnie niepotrzebnymi. Scjentyzm nie docenił rozumu, który działa w ramach swoich kompetencji. Rozum został przez scjentyzm przeceniony. I dlatego, gdy dąży się do unaukowienia wszystkich dziedzin przez stosowanie w nich metody nauk przyrodniczych, prowadzi to do pozbawienia badań właściwych kompetencji ${ }^{44}$.

\section{Wnioski końcowe}

Chrześcijańska pedagogika personalistyczna, zachowując swój status „krytycznej świadomości" wobec innych orientacji czy koncepcji wychowania, nie stawia siebie wyżej od nich, lecz podejmuje z nimi dialog i proponuje własne próby wyjaśniania rzeczywistości wychowawczej. Wskazuje na jednostronność lub ograniczoność pewnych propozycji, co zostało zasygnalizowane w niniejszym artykule. Jednocześnie proponuje korzystanie z odniesień teologicznych, które poszerzają krag widzenia problemów pedagogiki o racje ostateczne, przekraczające ludzki krąg doświadczenia i rozumowania.

Wychowanie i pedagogika katolicka powinny dawać szczególne świadectwo tym wartościom, które cenią wszyscy ludzie, choć być może na różne sposoby, unikać absolutyzowania, dawać przykład pedagogii odznaczającej się miłością do człowieka i wolnością, która ma swoje źródło w Bogu. Należy to czynić bez

${ }^{43}$ B. Śliwerski, Wspótczesne teorie, s. 384.

${ }^{44}$ P. Tomasik, Encyklika „Fides et ratio” jako inspiracja dla wychowania katolickiego, „Katecheta" 2 (1999), s. 12. 
dogmatyzmu, bez pragmatyzmu i bez kompleksów. Jednym z zadań chrześcijańskiego wychowania jest „czynić świat bardziej ludzkim” i „przywrócić go Bogu”. Działalność wychowawcza ma także służyć procesom wyzwolenia i humanizacji, a w perspektywie ostatecznej - zbawieniu człowieka ${ }^{45}$.

Nie bez znaczenia jest również fakt, że chrześcijańska inspiracja w pedagogice liczy sobie już dwa tysiące lat

tradycji wychowania w miłości do człowieka i w ukazywaniu ojcostwa Boga, które stanowi centralny punkt i istotę chrześcijańskiej inspiracji w pedagogice, a którego odbiciem na płaszczyźnie stosunków międzyludzkich jest braterstwo. Podobnie jak twórcy wielu współczesnych koncepcji wychowania, zatroskani o postęp ludzkości i rozwój człowieka, o wolność i demokratyzację życia itp., również chrześcijanie opowiadają się za wolnością i równością, wiedzą jednak, że mogą one być osiągnięte w perspektywie prawdy o braterstwie ludzi, wynikającej z uznania Ojcostwa Boga, będącego zarazem 'Praźródłem' ludzkiego ojcostwa i macierzyństwa, które interpretujemy na nowo w świetle paidei Zmartwychwstatego Pana ${ }^{46}$.

Istnieje pewne ryzyko błędnej aplikacji zasad wynikających z chrześcijańskiej pedagogiki personalistycznej. Takim błędem może stać się spirytualizm lub abstrakcyjny intelektualizm, które jakby zapominały o wymiarze cielesnym (materialnym) i historycznym życia ludzkiego. Inny błąd może przybrać postać nieproporcjonalnej reakcji wobec wszelkich odniesień wspólnotowych, co na ogół przeradza się w indywidualizm lub liberalizm indywidualistyczny. Na trzecim miejscu klasyfikuje się tendencja do zamykania całego procesu wychowawczego w klamrach czysto opisowych, zapominając o jego charakterze dynamicznym i historycznym. Wymienione błędy mogą negatywnie wpłynąc na podejmowane działania wychowawcze w wymiarze treści, celów, środków i metod wychowania. Pocieszające jednak jest to, że poglądy i idee wychowawcze są niewątpliwie bardzo ważne, ale one same nie wychowuja - wychowuje (i wychowuje się) konkretny człowiek. Według ks. J. Tarnowskiego, pedagogika przyszłości musi być „pedagogiką o ludzkim obliczu”, zakorzenioną na gruncie chrześcijańskim i wyrażającą się autentycznym dialogiem (dialog jako metoda, dialog jako proces, dialog jako postawa $)^{47}$.

${ }^{45}$ Por. M. Nowak, Podstawy pedagogiki, s. 32-33.

${ }^{46}$ Tamże, s. 34.

${ }^{47}$ Por. B. Śliwerski, Współczesne teorie, s. 70-71. 


\section{La pedagogia personalista cristiana e le concezioni contemporanee dell'educazione (Riassunto)}

Questo articolo presenta un confronto critico tra le principali correnti della pedagogia contemporanea (l'indirizzo personalista, l'indirizzo laico neo-illuminista, l'indirizzo moderno e neo-radicale, l'indirizzo tecnologico-funzionalista) con lo scopo di valutarle, prendendo come punto di riferimento le linee fondamentali della pedagogia personalista cristiana. Essa riconosce la Rivelazione come "criterio negativo" per valutare le varie concezioni educative, soprattutto dal punto di vista delle affermazioni antropologiche ed assiologiche. Questo ruolo di “coscienza critica” spetta anche alla pedagogia personalista, che interviene nel dibattito pedagogico, da un lato in difesa dei diritti e della dignità personale, dall'altro per richiamare l'attenzione sulla necessaria vigilanza epistemologica delle asserzioni pedagogiche.

Partendo da questi presupposti, sono state valutate le correnti più significative della pedagogia contemporanea per dimostrare che alcune idee e impostazioni educative sono in contrasto con la pedagogia d'ispirazione cristiana. Queste differenze riguardano, ad esempio, il modo di vedere l'educazione, la funzione educativa, il contributo della pedagogia come scienza (dal naturalismo pedagogico di J. J Rousseau alla anti-pedagogia fino alla concezione post-moderna), il problema del pluralismo culturale ed educativo, la visione dei fini educativi, la questione del relativismo e dell'individualismo nel campo della conoscenza e della morale e, infine, le istituzioni educative.

Molto spesso teorie pedagogiche si ritrovano come ideologie pedagogiche di sistemi e prassi politiche. Più specificamente, si presentano sotto forma di mentalità o di atteggiamenti generali riguardanti l'educazione e la "scienza" che ne scaturisce, confortati dai risultati della riflessione critica e magari da approfondimenti filosofici, nel senso stretto del termine.

A livello di azione educativa concreta, questi indirizzi teorici entrano spesso in conflitto con le possibilità soggettive di educazione e con le concrete richieste e opportunità sociali di sviluppo umano. Questa tensione dovrebbe tuttavia evitare ogni forma di accentuazione unilaterale e riduzionistica. 